\title{
Impact of unilateral eyestalk ablation on major biochemical parameters of muscle of the freshwater crab Travancoriana schirnerae Bott, 1969 (Decapoda: Gecarcinucidae)
}

\section{Latha Nadkandi Padmanabhan and Sudha Devi Arath Raghavan*}

Department of Zoology and Research Centre. Mary Matha Arts and Science College. Mananthavady. Wayanad, Kerala. India.*Email: arsudhadevi@gmail.com.

\begin{abstract}
The current study examined the moultwise impact of unilateral eyestalk ablation on major biochemical parameters of the muscle of the freshwater crab Travancoriana schirnerae Bott, 1969 (Decapoda: Gecarcinucidae). Meat from unilaterally destalked crabs 15 days post-operation was analyzed for protein, oligosaccharide, polysaccharide, total free amino acid, total lipid, cholesterol and moisture content following standard procedures. The results indicated a moultwise cycling of the major biochemical parameters of the muscle. Unilateral eyestalk ablation induced a rise in all the major biochemical parameters except moisture, irrespective of the moult stages. The alteration induced as an impact of unilateral destalkation in the biochemical parameters decide the suitability of this technique to enhance meat quality as practiced in aquaculture farms of marine decapods.
\end{abstract}

Keywords: Cholesterol; Protein; Total free amino acid; Total lipid; $\mathrm{X}$-organ sinus gland complex.

\section{Introduction}

In crustaceans, the $\mathrm{X}$-organ sinus gland (XO-SG) complex located in the eyestalks synthesizes and releases a number of neuropeptide hormones such as gonad inhibiting hormone (GIH), mandibular organ inhibiting hormone (MO-IH), crustacean hyperglycemic hormone $(\mathrm{CHH})$ and moult inhibiting hormone (MIH) which play important roles in growth and reproduction. These hormones also play a
Received

March 29, 2016

Accepted

September 2, 2016

Released

December 31, 2016

Open Acess Full Text Article

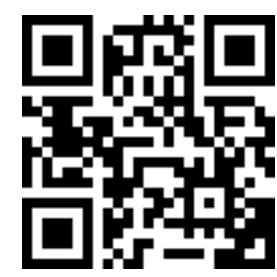

ORCID
(1) 0000-0002-7390-9659
Latha Nadkandi
Padmanabhan
(1) 0000-0003-4062-8073
Sudha Devi Arath
Raghavan role in the metabolism of proteins, lipids, nitrogen, calcium, carbohydrates and water balance (Highnam and Hill, 1979; Beltz, 1988; Chang, 1992). The accumulation and consequent release of stored organic reserves from different tissues to a large extent are influenced by the regulatory and inhibitory actions of XO-SG hormones. Loss of one or both the eyestalks induces significant alterations in stored reserves, consequently modifying the quality of edible tissues. Ablation of one or both the 
eyestalks is performed in aquaculture farms to induce early maturation in juveniles, so as to obtain mature adults with enhanced meat quality much ahead of the time taken under normal conditions (Santiago, 1977; Primavera, 1978; Lin et al., 2001).

The relative concentrations of biochemical components in muscle vary during the course of a normal moult cycle in crustaceans. In the freshwater crayfish Orconectes virilis, O'Connor and Gilbert (1969) observed that initiation of premoult activity resulted in increased lipid content of the abdominal muscle. Studies by Spindler-Barth (1976) in the shore crab Carcinus maenas observed a rise in the muscle glycogen content of premoult animals without significant variation in the haemolymph glucose throughout the moult cycle. In the land crab Gecarcinus lateralis, free amino acid pools in the haemolymph were lower and more variable than those in the muscle, which showed a three-fold decrease during premoult in comparison to intermoult period (Yamaoka and Skinner, 1976). Mid premoult increase in lipid content with late premoult decrease was recorded in the freshwater shrimp Palaemon paucidens (Teshima and Kanazawa, 1976). Suneetha et al. (2009) reported a rapid synthesis of lipid and protein content in the muscle from postmoult to premoult stage in the shrimp Penaeus monodon. Higher protein, carbohydrate and lipid levels were recorded in the hard-shelled swimmer crab Portunus sanguinolentus (Sudhakar et al., 2009a). Paray et al. (2014) observed that the protein content of muscle and hepatopancreas peaked during postmoult and gradually declined in intermoult and premoult stages of the shrimp Portunus semisulcatus.

Changes in the biochemical composition of various tissues due to eyestalk ablation is extensively studied in decapod crustaceans (Sainz-Hernández et al., 2008; Khazraeenia and Khazraiinia, 2009; Wu et al., 2013; Padmanabhan and Raghavan, 2016). Unilateral eyestalk ablation reportedly improved the protein, carbohydrate, lipid, ash, amino acid and moisture content in the muscle of portunid crabs Charybdis lucifera and Portunus sanguinolentus (Murugesan et al., 2008; Sudhakar et al., 2009b). Less attention has been paid with regard to moultwise impact of eyestalk ablation on the biochemical composition of freshwater decapods. Koshio et al. (1992) and Soundarapandian and Ananthan (2008) studied the impact of unilateral destalkation on the muscle biochemical components of juvenile Macrobrachium rosenbergii and Macrobrachium malcolmsonii, respectively. The freshwater crab Travancoriana schirnerae commonly inhabiting the wetlands of Wayanad district, Kerala, India, forms an essential part of the traditional food regime of the local tribal population.

The present study on moultwise impact of unilateral eyestalk ablation on the biochemical composition of Travancoriana schirnerae Bott, 1969 (Decapoda: Gecarcinucidae) meat would be the first report of its kind. The knowledge generated from this study will help to decide the suitability of unilateral eyestalk ablation to enhance meat quality, as practiced in aquaculture farms of marine decapods.

\section{Materials and methods}

Adult crabs (carapace width 4.0$5.0 \mathrm{~cm}$ ) in different moult stages were collected from the paddy fields of Ondayangadi, about $5 \mathrm{~km}$ Northeast of Mananthavady $\left(11.82^{\circ} \mathrm{N}\right.$ and $76.02^{\circ} \mathrm{E}$, altitude $767 \mathrm{~m}$ ) in Wayanad district of Kerala. They were immediately brought to the laboratory and maintained in clean plastic tubs. The body weight and moult stages were recorded. The moult stages were ascertained by microscopic examination of setal development in the epipodite of the third maxilliped of males and pleopods in the case of females.

Unilateral eyestalk ablation was carried out on the third day after acclimatization. The crabs were cleaned under running tap water, dried and swabbed with $70 \%$ alcohol. With a pair of sterilized scissors, the right eyestalk was carefully ablated from the base; the wound was quickly cauterized with a blunt, red hot needle to prevent bleeding (Caillouet, 
1972). Antiseptic powder was applied on the wound and sealed with cotton. Unablated control and eyestalk ablated crabs were placed in separate tubs. On 15th day, both the control and ablated crabs were sacrificed. Freshly dissected meat was weighed and used for analyses. Protein, carbohydrate and lipid contents were analyzed adopting standard methods (Lowry et al., 1951; Dubois et al., 1956; Folch et al., 1957; Frings et al., 1972; Johnston and Davies, 1972).

Total free amino acid (FAA) and cholesterol contents were estimated according to Lee and Takahashi (1966) and Zlatkis et al. (1953), respectively.

To determine the moisture content, one gram of freshly dissected meat was kept in the oven at $105{ }^{\circ} \mathrm{C}$ and weighed at regular intervals until a constant weight was obtained. The difference between the wet and dry weights was expressed as percentage in terms of wet weight of the tissue (Pillay and Nair, 1973).

Analyses were carried out in pentaplicate and the results were presented as Mean \pm SD. The data was analyzed by one-way analysis of variance (ANOVA), using SPSS 16 software.

\section{Results}

The moultwise variation in the major biochemical constituents: protein, oligosaccharide and polysaccharide, total FAA, total lipid, cholesterol and moisture in the muscle of unilaterally destalked Travancoriana schirnerae is presented in Table 1.

Table 1. Impact of unilateral eyestalk ablation on major biochemical components in the muscle of Travancoriana schirnerae during different moult stages.

\begin{tabular}{|l|c|c|c|c|c|c|}
\hline \multirow{2}{*}{} & \multicolumn{2}{|c|}{ Intermoult } & \multicolumn{2}{c|}{ Premoult } & \multicolumn{2}{c|}{ Postmoult } \\
\cline { 2 - 7 } & Control & UESA & Control & UESA & Control & UESA \\
\hline Protein (\%) & $19.81 \pm 2.38$ & $23.68 \pm 2.61^{*}$ & $26.75 \pm 3.51$ & $29.44 \pm 4.05^{*}$ & $17.13 \pm 1.96$ & $19.35 \pm 3.05^{*}$ \\
\hline Oligo (\%) & $0.500 \pm 0.20$ & $0.658 \pm 0.145^{*}$ & $0.743 \pm 0.262$ & $1.011 \pm 0.266^{*}$ & $0.442 \pm 0.057$ & $0.607 \pm 0.128^{*}$ \\
\hline Poly (\%) & $0.575 \pm 0.19$ & $0.888 \pm 0.294^{*}$ & $0.790 \pm 0.133$ & $1.205 \pm 0.339^{*}$ & $0.432 \pm 0.116$ & $0.584 \pm 0.105^{*}$ \\
\hline FAAc (mg/100 g) & $2029 \pm 389$ & $2655 \pm 551^{*}$ & $2106 \pm 278$ & $2821 \pm 473^{*}$ & $1814 \pm 391$ & $1989 \pm 312^{*}$ \\
\hline Total lipid (mg/100 g) & $363.42 \pm 90.44$ & $389.35 \pm 112.89^{\#}$ & $390.36 \pm 34.42$ & $407.81 \pm 41.45^{\#}$ & $205.56 \pm 50.04$ & $249.88 \pm 31.39^{*}$ \\
\hline Cholesterol (mg/100 g) & $22.87 \pm 4.41$ & $29.10 \pm 8.38^{*}$ & $26.36 \pm 6.25$ & $44.34 \pm 6.40^{*}$ & $18.52 \pm 6.670$ & $24.79 \pm 8.29^{*}$ \\
\hline Moisture (\%) & $80.03 \pm 2.73$ & $81.87 \pm 2.56^{\#}$ & $80.50 \pm 1.52$ & $81.30 \pm 1.31^{\#}$ & $80.94 \pm 1.590$ & $81.42 \pm 1.75^{\#}$ \\
\hline
\end{tabular}

The values are represented as Mean \pm SD, FAA: total free amino acid, UESA: unilaterally eyestalk ablated crabs, ${ }^{*} \mathrm{p}<0.05, \# \mathrm{p}>0.05$.

Unilateral eyestalk ablation induced a significant rise in the muscle protein content irrespective of the moult stages. In the intermoult control animals, protein content recorded $19.81 \pm 2.38 \%$ and in eyestalk ablated crabs it increased significantly to $23.68 \pm 2.61 \%$. The highest protein content was noticed in the unilaterally eyestalk ablated premoult crabs $(29.44 \pm 4.05 \%)$ which was significantly higher than the control group $(26.75 \pm 3.51 \%)$. In the postmoult stage, protein content increased significantly from $17.13 \pm 1.96 \%$ in control crabs to $19.35 \pm 3.05 \%$ in the experimentals (Figure 1).

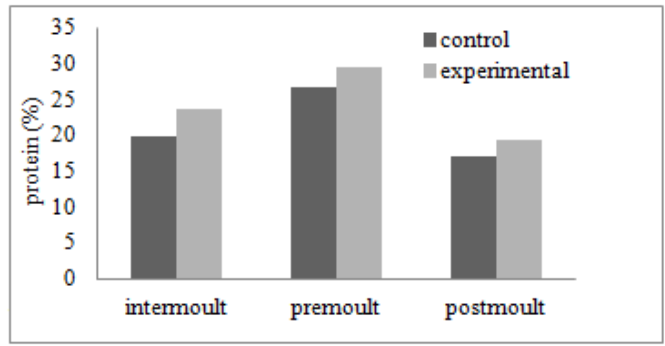

Figure 1. Variation in the protein content of muscle of control and experimental crabs during different moult stages.

Statistically significant rise in the oligosaccharide content was discernible in the experimental group $(0.658 \pm 0.14 \%)$ in 
comparison to the intact controls $(0.500 \pm 0.20 \%)$ of the intermoult stage. Unilateral destalkation also displayed a significant increase in oligosaccharide content $(1.01 \pm 0.26 \%)$ in premoult crabs, compared to their control counterparts $(0.743 \pm 0.26 \%)$. Though a sharp decline in the oligosaccharide content was observed in the control crabs of the postmoult stage $(0.442 \pm 0.05 \%)$, unilateral ablation showed a significant rise in this value (0.607 $\pm 0.12 \%)$ (Figure 2).

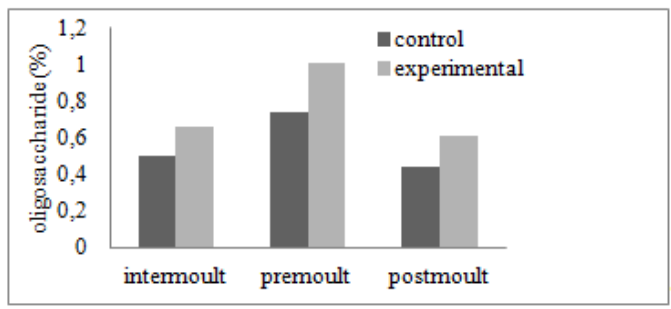

Figure 2. Changes in the muscle oligosaccharide content in response to unilateral eyestalk ablation.

In the unablated crabs, from intermoult to the premoult stage, the muscle polysaccharide content demonstrated a steady increase, thereafter declining to its lowest value in the postmoult stage. The differences in the polysaccharide contents of intermoult control $(0.575 \pm 0.19 \%)$ and experimental $(0.888 \pm 0.29 \%)$ crabs were found to be statistically significant. Among the experimental animals of the three moult stages, premoult crabs recorded the highest value for polysaccharide content $(1.205 \pm 0.33 \%) \quad$ while their controls recorded $0.790 \pm 0.13 \%$. In postmoult animals, unilateral eyestalk ablation induced a significant upsurge in the muscle polysaccharide content from $0.432 \pm 0.11 \%$ to $0.584 \pm 0.10 \%$ (Figure 3).

In the intermoult crabs, the total FAA content of the muscle increased significantly from $2,029 \pm 389 \mathrm{mg} / 100 \mathrm{~g}$ to $2,655 \pm 551 \mathrm{mg} / 100 \mathrm{~g}$ in response to unilateral eyestalk ablation. Similar tendency was noticed in the premoult crabs (control 2,106 $\pm 278 \mathrm{mg} / 100 \mathrm{~g}$; experimental 2,821 $\pm 473 \mathrm{mg} / 100 \mathrm{~g}$ ). Postmoult control crabs recorded the lowest values for total FAA content $(1,814 \pm 391 \mathrm{mg} / 100 \mathrm{~g})$ which increased significantly to $1,989 \pm 312 \mathrm{mg} / 100 \mathrm{~g}$ in experimentals (Figure 4).

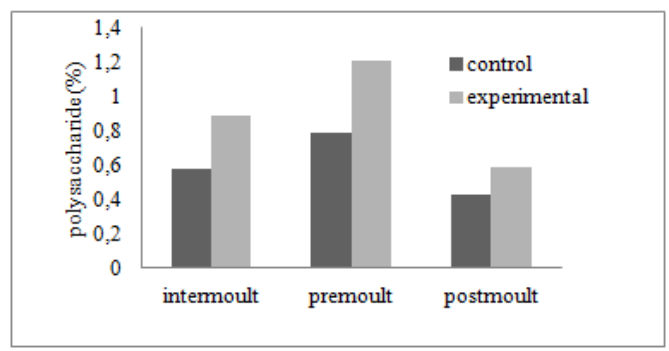

Figure 3. Polysaccharide content in the muscle of unablated and unilaterally ablated crabs during different moult stages.

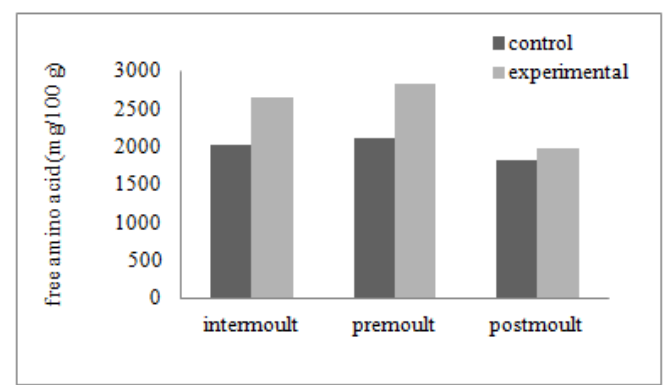

Figure 4. Changes in the total free amino acid content in response to unilateral eyestalk ablation.

Though unilateral eyestalk removal induced a rise in the total lipid content of intermoult (389.35 $\pm 112.89 \mathrm{mg} / 100 \mathrm{~g})$ and premoult individuals (407.81 \pm 41.45 $\mathrm{mg} / 100 \mathrm{~g})$ compared to their controls (363.42 $\pm 90.44 \quad \mathrm{mg} / 100 \mathrm{~g}$ and $390.36 \pm 34.42 \mathrm{mg} / 100 \mathrm{~g}$, respectively), it was not statistically significant ( $p>0.05$ ). Control crabs of the postmoult stage recorded the lowest lipid content (205.56 $\pm 50.04 \mathrm{mg} / 100 \mathrm{~g}$ ) which increased significantly to $249.88 \pm 31.39 \mathrm{mg} / 100 \mathrm{~g}$ in destalked animals (Figure 5).

Destalkation induced a significant upsurge in the muscle cholesterol levels of intermoult crabs $(29.10 \pm 8.38 \mathrm{mg} / 100 \mathrm{~g})$ from their controls $(22.87 \pm 4.41 \mathrm{mg} / 100$ g). In premoult crabs, unilateral eyestalk ablation increased the cholesterol content significantly from $26.36 \pm 6.25$ to $44.34 \pm 6.40 \mathrm{mg} / 100 \mathrm{~g}$. Cholesterol content in unablated postmoult crabs recorded $18.52 \pm 6.67 \mathrm{mg} / 100 \mathrm{~g}$, which increased 
significantly to $24.79 \pm 8.29 \mathrm{mg} / 100 \mathrm{~g}$ in ablated crabs (Figure 6).

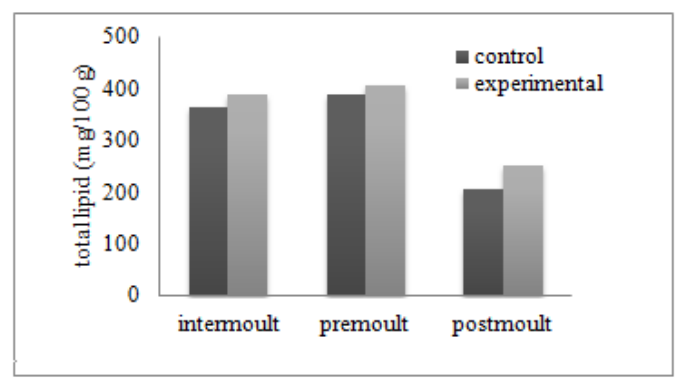

Figure 5. Impact of unilateral eyestalk ablation in the total lipid content of muscle during different moult stages.

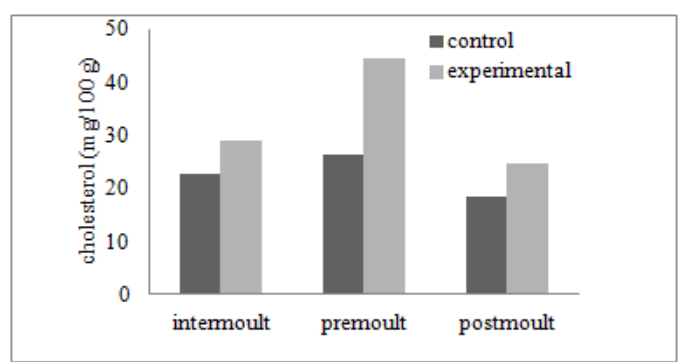

Figure 6. Bar graph illustrating changes in the muscle cholesterol content of control and unilaterally destalked crabs in different moult stages.

Unilateral eyestalk ablation did not induce any moultwise variation in the muscle moisture levels. The moisture content in control crabs of the intermoult stage was $80.03 \pm 2.73 \%$ which showed no significant rise to $81.87 \pm 2.56 \%$ in response to unilateral eyestalk ablation. The same pattern was observed among normal and destalked crabs of premoult (control $80.50 \pm 1.52 \%$; experimental $81.30 \pm 1.31 \%)$ and postmoult stages (control $80.94 \pm 1.59 \%$; $\quad$ experimental $81.42 \pm 1.75 \%$ ) (Table 1$)$.

\section{Discussion}

The present study revealed that unilateral destalkation during different moult stages induced a rise in the muscle biochemical components except moisture. In control animals, the values demonstrated an increasing trend from the postmoult to premoult stages. It is well known that crustaceans accumulate nutrients prior to moulting to provide enough energy for ecdysis. Passano (1960) proposed that biochemical processes are more pronounced than morphological changes during early premoult stages.

Our observations revealed a significant increase in the average protein value of unilaterally destalked Travancoriana schirnerae in all the three moult stages. In agreement with the present findings, unilateral eyestalk ablation demonstrated a significant rise in the protein content of marine intermoult crabs Charybdis lucifera and Portunus sanguinolentus (Murugesan et al., 2008; Sudhakar et al., 2009b). In contrast, Koshio et al. (1992) reported that the intermoult protein contents of the whole body remained unaltered in unilaterally destalked Macrobrachium rosenbergii. Among control Travancoriana schirnerae, the highest value for muscle protein was recorded in premoult crabs and lowest in postmoult crabs. Studies by Suneetha et al. (2009) in the muscle of Penaeus monodon showed that rapid synthesis of protein occurs from postmoult to premoult stages. Sudhakar et al. (2009a) documented that protein content of hard-shelled Portunus sanguinolentus increased significantly when compared to the soft-shelled crabs. However, protein content peaked during the postmoult stage, gradually declined during intermoult and premoult stages in the muscle of Portunus semisulcatus (Paray et al., 2014).

In Travancoriana schirnerae, the oligo and polysaccharide reserves in the muscle recorded a significant rise as a result of unilateral ablation in all the three moult stages. Similar rise was reported in the carbohydrate content of unilaterally destalked intermoult Charybdis lucifera and Portunus sanguinolentus (Murugesan et al., 2008; Sudhakar et al., 2009b). The free sugar content in the muscle of the field crab Oziotelphusa senex senex showed an increase following eyestalk extirpation (Venkataramanaiah and Ramamurthi, 1980). Many authors have investigated the 
variation in carbohydrate content as a result of destalkation. Bilateral destalkation during intermoult induced an increase in the muscle glycogen concentration of the freshwater crabs Paratelphusa jacquemontii (Rangnekar et al., 1961) and Varuna litterata (Madhyastha and Rangnekar, 1976). Rao et al. (1985) observed that loss of eyestalks resulted in increased muscle glycogen concentration of intermoult fiddler crabs Uca annulipes and Uca triangularis. Rangnekar and Madhyastha (1971) and Nagabhushanam and Kulkarni (1980) noticed a significant rise in muscle glycogen content of bilaterally destalked Metapenaeus monoceros and Parapenaeopsis hardwickii, respectively. Wang and Scheer (1963) reported that the enzyme uridine diphosphate glucoseglycogen transglucosylase (UDPG-GT), which converts glucose to glycogen in the muscle, is under the control of eyestalk hormones. The significant rise in the muscle carbohydrate content in the present study may be attributed to the partial removal of eyestalk hormones as a result of unilateral destalkation. In contrast, unilateral eyestalk ablation did not affect the carbohydrate content of Macrobrachium malcolmsonii during intermoult stage (Soundarapandian and Ananthan, 2008).

Among control Travancoriana schirnerae, the premoult stage recorded comparatively higher values for oligo and polysaccharides than the postmoult and intermoult stages. Similar observations were made by Spindler-Barth (1976) in Carcinus maenas where the muscle glycogen concentration reached maximum value during premoult stage.

The total FAA content in the muscle of unilaterally ablated Travancoriana schirnerae showed statistically significant rise during the three moult stages. Likewise, unilateral destalkation in intermoult Orconectes virilis caused increased FAA level in the muscle within 24 hours (McWhinnie et al., 1972). The haemolymph FAA content recorded a significant rise in unilaterally ablated $M$. monoceros (Surendranath et al., 1992). Soundarapandian and Ananthan (2008) reported that unilateral destalkation led to enhanced levels of total FAA in the whole body of juvenile Macrobrachium malcolmsonii. Conversely, bilateral destalkation led to decreased FAA content in the muscle and haemolymph of the intermoult freshwater crab Barytelphusa guerini (Gangothri et al., 1988).

The increase in FAA content observed in experimental crabs of the present investigation may be ascribed to the changes in protein metabolism likely to have been initiated by the partial removal of eyestalk hormones. In intact Travancoriana schirnerae, the total FAA levels increased steadily from postmoult to premoult stages. Comparable results were noticed in Orconectes virilis, where the muscle FAA levels increased two to three-fold during premoult stage (McWhinnie et al., 1972). High amino acid content was recorded in the muscle of premoult Penaeus monodon, which reached significantly lower levels during postmoult stage (Faadila et al., 2013). Conversely, total FAA content in the muscle of Gecarcinus lateralis decreased almost three-fold during the premoult period compared to the intermoult period (Yamaoka and Skinner, 1976). In the blue crab Callinectes sapidus, the whole body tissue FAA content was maximum in the intermoult stage, declined during premoult and remained low in postmoult condition (Wheatly, 1985).

The current investigation has observed an increase in the muscle lipid content of destalked crabs irrespective of the moult stages. Similar results were documented from the body tissue of intermoult unilaterally destalked Charybdis lucifera and Portunus sanguinolentus three days post-operation (Murugesan et al., 2008; Sudhakar et al., 2009b). Diwan (1973) recorded an increase in lipid content on account of eyestalk ablation in the edible muscle of Barytelphusa cunicularis. However, no significant change in fat content of the muscle was noticed after bilateral eyestalk removal in Varuna litterata and Parapenaeopsis hardwickii (Madhyastha and Rangnekar, 1976; Nagabhushanam and Kulkarni, 1980). Rao et al. (1985) observed that bilateral eyestalk 
ablation induced a decrease in the fat content of muscle of fiddler crabs. Unilateral eyestalk ablation did not alter the whole body lipid content in Macrobrachium rosenbergii (Koshio et al., 1992).

As observed in our study, a progressive increase in the lipid content of the abdominal muscle from intermoult to premoult stages was recorded in Orconectes virilis (O’Connor and Gilbert, 1969) and Penaeus monodon (Suneetha et al., 2009). In contrast, investigations of Tanikawa et al. (1958) in the king crab Paralithodes camtschatica revealed that soft-shelled meat contained larger amounts of crude fat than the hard-shelled meat. Kanazawa et al. (1976) observed almost same levels of muscle lipids throughout the moult stages in Penaeus japonicus. The increase in muscle lipid during the premoult period is crucial, which will be utilized as an energy source for the subsequent moulting process. Muscle lipid is a major contributor for muscle revival after ecdysis, acting as a reservoir for the production of cellular and subcellular membranes, which is exhausted after postmoult stage (O'Connor and Gilbert, 1969).

In the present investigation, muscle cholesterol content recorded a significant rise in the experimental groups compared to the intact crabs of the three moult stages. In agreement with our observations, eyestalk ablation caused significant rise in muscle cholesterol concentration of intermoult Sesarma boulengeri (Sinha and Mooswi, 1978). On the contrary, Teshima (1978) reported that cholesterol content in the muscle of unilaterally eyestalk ablated intermoult Penaeus japonicus was slightly lower than that of unablated group. Arcos et al. (2003) recorded significant decrease in the haemolymph cholesterol levels eight days post unilateral ablation in intermoult Litopenaeus vannamei. In the same species, Sainz-Hernández et al. (2008) observed that neither unilateral nor bilateral eyestalk ablation induced any significant difference in the haemolymph cholesterol concentration. The muscle cholesterol content in eyestalk intact Travancoriana schirnerae gradually increased from postmoult to premoult stages. However, such moultwise variations were not recorded in the muscle of Penaeus japonicus (Kanazawa et al., 1976). Cholesterol content did not show moultwise fluctuations in haemolymph and hepatopancreas of juvenile Farfantepenaeus duorarum (BonillaGómez et al., 2012).

In the current investigation, unilateral eyestalk ablation did not induce any significant difference in the muscle moisture content between the moult stages. This observation reveals that eyestalk principles do not play a role in the regulation of water content of the muscle tissue. Similarly, unilateral destalkation did not yield significant variation in moisture content of the muscle in juvenile Macrobrachium malcolmsonii (Soundarapandian and Ananthan, 2008) and adult Portunus sanguinolentus (Sudhakar et al., 2009b). Conversely, investigations in juvenile Homarus americanus revealed significantly higher muscle tissue water content in response to destalkation (Charmantier et al., 1984; Jackson et al., 1987). In destalked intermoult Ocypode macrocera, significant increase in moisture content was recorded in the first 24 hours until the eighth day of the experiment (Bhat et al., 2012).

In the current study, a moultwise fluctuation was not observed in moisture content of the muscle. Comparable observations were noticed by Cesar et al. (2006) in the moult stages of Litopenaeus vannamei. In Penaeus monodon, no marked variation in the muscle moisture content was reported during different moult stages (Faadila et al., 2013). However, Travis (1957) showed a higher proportion of water at ecdysis and early postmoult stage, declined in early premoult before rising again at late premoult stage in the spiny lobster Panulirus argus. In Penaeus monodon, Suneetha et al. (2009) observed that the whole body moisture content declined steadily as the animal progressed to the premoult stage from the postmoult stage. 


\section{Acknowledgements}

The Junior Research Fellowship by the Kannur University to the first author is gratefully acknowledged.

\section{Conflict of interest statement}

Authors declare that they have no conflict of interests.

\section{References}

Arcos, G. F.; Ibarra, A. M.; Vazquez-Boucard, C.; Palacios, E.; Racotta, I. S. Haemolymph metabolic variables in relation to eyestalk ablation and gonad development of Pacific white shrimp Litopenaeus vannamei Boone. Aquacult. Res., v. 34, p. 749-755, 2003. http://dx.doi.org/10.1046/j.1365-2109.2003.00878.x

Beltz, B. S. Crustacean Neurohormones. In: Laufer, H.; Downer, R. G. H. (Eds.). Endocrinology of selected invertebrate types. New York: Alan R. Liss Inc., 1988. p. 235-258.

Bhat, B. A.; Elanchezhiyan, C.; Ravichandran, S.; Allayie, S. A.; Hemalatha, S.; Manoharan, V.; Rathaer, S. A.; Bhat, M. I. Neuroendocrine control of water content and calcium concentration in the crab, Ocypode macrocera (H. Milne Edwards 1852) (Brachyura, Ocypodae). Pak. J. Biol. Sci., v. 15, p. 296-300, 2012. http://dx.doi.org/10.3923/pjbs.2011.296.300

Bonilla-Gómez, J. L.; Chiappa-Carrara, X.; Galindo, C.; Jeronimo, G.; Cuzon, G.; Gaxiola, G. Physiological and biochemical changes of wild and cultivated juvenile pink shrimp Farfantepenaeus duorarum (Crustacea: Penaeidae) during molt cycle. J. Crust. Biol., v. 32, p. 597-606, 2012. http://dx.doi.org/10.1163/1932724012X630679

Caillouet, C. W. Ovarian maturation by eyestalk ablation in pink shrimp Penaeus duorarum Barkenroad. Proceedings of the Third Annual Workshop of the World Mariculture Society, v. 3, p. 205-225, 1972. http://dx.doi.org/10.1111/j.1749-

7345.1972.tb00064.x

Cesar， J. R. D. O.; Zhao， B.; Spencer， M.; Harry, A. K. O.; Yang, J. Morphological and biochemical changes in the muscle of the marine shrimp Litopenaeus vannamei during the molt cycle. Aquaculture, v. 261, p. 688-694, 2006. http://dx.doi.org/10.106/j.aquaculture.2006.08.003

Chang, E. S. Endocrinology. In: Fast, A. W.; Laster, J. (Eds.). Marine shrimp culture: principles and practices. Amsterdam: Elsevier, 1992.

Charmantier, G.; Charmantier-Duares, M.; Aiken, D. E. Neuroendocrine control of hydromineral regulation in the American lobster, Homarus americanus (H. Milne Edwards 1837) (Crustacea, Decapoda). Gen. Comp. Endocrinol., $\quad$ v. 54, p. 8-19, 1984. http://dx.doi.org/10.1016/0016-6480(84)90193-X

Dubois, M.; Gilles, K. A.; Hamilton, J. K.; Rebers, P. A.; Smith, F. Colorimetric method for determination of sugars and related substances. Anal. Chem., v. 28, p. 350-356, 1956. http://dx.doi.org/10.1021/ac60111a017

Diwan, A. D. Neuroendocrine regulation of glycogen and fat content in the hepatopancreas and muscle tissue of the freshwater crab, Barytelphusa cunicularis. Marathwada Univ. J. Sci., v. 12, p. 279-284, 1973.

Faadila, N. M. I.; Harivaindaran, K. V.; Yang, $\mathrm{T}$. A. Biochemical and texture property changes during molting process of tiger prawn, Penaeus monodon. Int. Food Res. J., v. 20, p. 751-758, 2013.

Folch, J.; Lees, M.; Sloane-Stanley, G. H. Simple method for the isolation and purification of total lipids from animal tissues. J. Biol. Chem., v. 226, p. 497-509, 1957. Available from: <http://www.jbc.org/content/226/1/497.long>. Accessed on: Feb. 23, 2016.

Frings, C. S.; Fendley, T. W.; Dunn, R. T.; Queen, C. A. Improved determination of total serum lipids by sulfo-vanillin reaction. Clin. Chem., v. 18, p. 673-674, 1972. Available from: $<$ http://www.clinchem.org/content/18/7/673.full.p dfthtml>. Accessed on: Feb. 23, 2016.

Gangothri, M. S.; Venkatachari, S. A. T.; Vasantha, N. Neuroendocrine control of protein and amino acid levels in the blood of freshwater crab, Barytelphusa guerini (H. Milne Edwards) (Decapoda, Potamidea). Curr. Sci., v. 57, p. 625-627, 1988. Available from: $<$ http://www.currentscience.ac.in/Downloads/ar ticle_id_056_20_1081_1083_0.pdf>. Accessed on: Feb. 23, 2016.

Highnam, H. C.; Hill, L. The comparative endocrinology of the invertebrates. London: Edward Arnold Publishers, 1979.

Jackson, S. A.; Bruce, M. J.; Chang, E. S.; Clegg, J.S. Effects of eyestalk ablation upon water relations in the American lobster, Homarus americanus. J. Exp. Zool., v. 244, p. 389-393, 1987. http://dx.doi.org/10.1002/jez.1402440306

Johnston, M. A.; Davies, P. S. Carbohydrates of the hepatopancreas and blood tissues of Carcinus. Comp. Biochem. Physiol., v. 41, 
p. 433-443, 1972. http://dx.doi.org/10.1016/03050491(72)90046-6

Kanazawa, A.; Teshima, S.; Tanaka, N. Nutritional requirements of prawn. V. Requirements for choline and inositol. Mem. Fac. Fish. Kagoshima Univ., v. 25, p. 47-51, 1976.

Khazraeenia, S.; Khazraiinia, P. Effects of bilateral eyestalk ablation on gonadal maturity, moulting and biochemical changes in the hemolymph of female crab Potamon persicum (Decapoda: Brachyura: Potamidae). Iran. J. Vet. Res., v. 3, p. 143-150, 2009.

Koshio, S.; Teshima, S. I.; Kanazawa, A. Effects of unilateral eyestalk ablation and feeding frequencies on growth, survival and body compositions of juvenile freshwater prawn Macrobrachium rosenbergii. Nip. Suis. Gak., v. 58, p. 1419-1425, 1992. http://doi.org/10.2331/suisan.58.1419

Lee, Y.P.; Takahashi, T. An improved colorimetric determination of amino acids with the use of ninhydrin. Anal. Biochem., v. 14, p. 71-77, 1966. http://dx.doi.org/10.1016/00032697(66)90057-1

Lin, J.; Zhang, D.; Creswell, R. Aquaculture of marine ornamental shrimps: an overview. Florida: The World Aquaculture Society, 2001. (Aquaculture Book of Abstracts).

Lowry, O. H.; Rosebrough, N. J.; Farr, A. L.; Randall, R. J. Protein measurement with the folin phenol reagent. J. Biol. Chem., v. 183, p. 265-275, 1951. Available from: <http://www.jbc.org/content/193/1/265.long>. Accessed on: Feb. 23, 2016.

Madhyastha, M. N.; Rangnekar, P. V. Metabolic effects of eyestalk removal in the crab Varuna litterata. Hydrobiologia, v. 48, p. 25-31, 1976. http://dx.doi.org/10.1007/BF00033487

McWhinnie, M. A.; Kirchberg, R. J.; Urbanski, R.; Schwarz, J. E. Crustecdysone mediated changes in crayfish. Amer. Zool., v. 12, p. 357372, 1972.

Murugesan, R.; Soundarapandian, P.; Manivannan, K. Effect of unilateral eyestalk ablation on the biochemical changes of edible portunid crab Charybdis lucifera (Fabricius). J. Fish. Aquat. Sci., v. 3, p. 82-86, 2008. http://dx.doi.org/10.3923/jfas.2008.82.86

Nagabhushanam, R.; Kulkarni, G. K. Role of eyestalk hormone in the carbohydrate metabolism of a marine penaeid prawn, Parapenaeopsis hardwickii (Miers) (Crustacea, Decapoda, Penaeidae). Hydrobiologia, v. 74, p. 145-150, 1980. http://dx.doi.org/10.1007/BF00014566
O’Connor, J. D.; Gilbert, L. I. Alterations in lipid metabolism associated with premolt activity in a land crab and freshwater crayfish. Comp. Biochem. Physiol., v. 29, p. 889-904, $1969 . \quad$ http://dx.doi.org/10.1016/0010406X(69)90992-X

Padmanabhan, L. N.; Raghavan, S. D. A. Impact of eyestalk ablation on androgenic gland activity in the freshwater crab Travancoriana schirnerae Bott, 1969 (Decapoda: Gecarcinucidae). Braz. J. Biol. Sci., v. 3, no. 5, p. 121-134, 2016. http://dx.doi.org/10.21472/bjbs.030511

Paray, B. A.; Jawahar Ali, A.; War, M.; Arun Kumar, M.S. Variation in the biochemical constituents during different moulting stages in green tiger shrimp, Penaeus semisulcatus. Ann. Res. Rev. Biol., v. 4, p. 985-997, 2014. http://dx.doi.org/10.9734/ARRB/2014/5798

Passano, L. M. Moulting and its control. In: Waterman, T. H. (Ed.). Physiology of Crustacea. New York: Academic Press, 1960. v. 1. p. 473-536.

Pillay, K. K.; Nair, N. B. Observations on the biochemical changes in gonads and other organs of Uca annulipes, Portunus pelagicus and Metapenaeus affinis (Decapoda: Crustacea) during the reproductive cycle. Mar. Biol., v. 18, p. 167-198, 1973. Available from: <http://repository.ias.ac.in/25762/1/307.pdf>.

Accessed on: Feb. 23, 2016.

Primavera, J. H. Induced maturation and spawning in five-month-old Penaeus monodon (Fabricius) by eyestalk ablation. Aquaculture, v. 13, p. 355-359, 1978. http://dx.doi.org/10.1016/0044-8486(78)90184-9

Rangnekar, P. V.; Sabins, P. B.; Nirmal, R. B. The occurrence of a hypoglycemic factor in the eyestalks of the freshwater crab Paratelphusa jacquemontii. J. Anim. Morphol. Physiol., v. 3, p. 137-144, 1961.

Rangnekar, P. V.; Madhyastha, M. N. Effect of eyestalk ablation on the carbohydrate metabolism of the prawn Metapenaeus monoceros (Fabricius). Indian J. Exp. Biol., v. 9, p. 462-464, 1971.

Rao, G. V. K.; Rao, Y. P.; Rao, D. G. V P. Changes in some biochemical constituents of the fiddler crabs Uca annulipes and $U$. triangularis (Milne Edwards) in response to eyestalk removal. Proc. Indian Acad. Sci., v. 94, p. 475-480, 1985.

Sainz-Hernández, J. C.; Racotta, I. S.; Dumas, S.; Hernández-López, J. Effect of unilateral and bilateral eyestalk ablation in Litopenaeus vannamei male and female on several metabolic and immunologic variables. Aquaculture, 
v. 283, $\quad$ p. 188-193, 2008. http://dx.doi.org/10.1016/j.aquaculture.2008.07.002

Santiago, A. C. Successful spawning of cultured Penaeus monodon (Fabricius) after eyestalk ablation. Aquaculture, v. 11, p. 185-196, 1977. http://dx.doi.org/10.1016/0044-8486(77)90111-9

Sinha, R. C.; Mooswi, H. K. Effect of eyestalk removal on the different biochemical constituents of muscle and hepatopancreas of the crab, Sesarma boulengeri (Calman). Comp. Physiol. Ecol., v. 3, p. 49-51, 1978.

Soundarapandian, P.; Ananthan, G. Effect of unilateral eyestalk ablation on the biochemical composition of commercially important juveniles of Macrobrachium malcolmsonii (H. Milne Edwards). Int. J. Zool. Res., v. 4, p. 106-112, 2008. http://dx.doi.org/10.3923/ijzr.2008.106.112

Spindler-Barth, M. Changes in the chemical composition of the common shore crab, Carcinus maenas, during the molting cycle. J. Comp. Physiol., v. 105, p. 197-205, 1976. http://dx.doi.org/10.1007/BF00691122

Sudhakar, M.; Manivannan, K.; Soundarapandian, P. Nutritive value of hard and soft shell crabs of Portunus sanguinolentus (Herbst). Int. J. Anim. Vet. Adv., v. 1, p. 4448, 2009a. Available from: $<$ http://maxwellsci.com/print/ijava/(2)49-

53.pdf $>$. Accessed on: Feb. 23, 2016.

Sudhakar, M.; Manivannan, K.; Soundarapandian, P.; Ananthan, G. Effect of unilateral eyestalk ablation on the biochemical changes of edible portunid crab, Portunus sanguinolentus (Herbst). Middle East J. Sci. Res., v. 4, p. 153-157, 2009b. Available from: $<$ http://www.idosi.org/mejsr/mejsr4(3)/6.pdf>. Accessed on: Feb. 23, 2016.

Suneetha, Y.; Sreenivasula Reddy, P.; Naga Jyothi, P.; Srinivasulu Reddy, M. Studies on the analysis of proximal changes during molting process in the penaeid prawn, Penaeus monodon. World J. Zool., v. 4, p. 286-290, 2009. Available from: <www.idosi.org/wjz/wjz(4).2009/6.pdf>.

Accessed on: Feb. 23, 2016.

Surendranath, P.; Ramanaiah, K.; Rao, K. V. R. Effect of eyestalk extract and kelthane on penaeid prawn Metapenaeus monoceros (Fabricus). Indian J. Mar. Sci., v. 30, p. 676679, 1992.
Tanikawa, E.; Wakasa, T.; Nagasawa, Y. Studies on the muscle meat of Paralithodes camtschatica. Bull. Fac. Fish. Hokkaido Univ., v. 11, p. 227-257, 1958.

Teshima, S. Essential fatty acids and necessity of sterols in crustaceans. In: Japanese Society of Scientific Fisheries (Ed.). Fish culture and dietary lipids. Tokyo: Koseisha-koseikaku, 1978. (Suisangaku Series No. 22). p. 60-77.

Teshima, S.; Kanazawa, A. Variation in lipid classes during the molting cycle of a shrimp (freshwater shrimp, Palaemon paucidens). Nip. Suis. Gak., v. 42, p. 1129-1135, 1976.

Travis, D. F. The molting cycle of the spiny lobster, Panulirus argus Latreille. IV. Postecdysial histological and histochemical changes in the hepatopancreas and integumental tissues. Biol. Bull., v. 1, p. 451-479, 1957.

Venkataramanaiah, D.; Ramamurthi, R. Endocrine control of carbohydrate metabolism in the freshwater crab Oziotelphusa senex senex Fabricius. I. Effect of eyestalk extirpation and eyestalk injection on carbohydrate levels. Comp. Physiol. Ecol., v. 5, p. 326-329, 1980.

Wang, D.-H.; Scheer, B. T. UDPGglycogentransglucosylase and a natural inhibitor in crustacean tissues. Comp. Biochem. Physiol., v. 9, p. 263-274, 1963. http://dx.doi.org/10.1016/0010-406X(63)90001-X Wheatly, M. G. Free amino acid and inorganic ion regulation in the whole muscle and hemolymph of the blue crab Callinectes sapidus (Rathbum) in relation to the molting cycle. $\mathbf{J}$. Crust. Biol., v. 5, p. 223-233, 1985. Available from: <http://www.jstor.org/stable/1547869>. Accessed on: Feb. 23, 2016.

Wu, J.; Kang, X.; Mu, S.; Tian, Z. Effect of eyestalk ablation in Eriocheir sinensis on physiological and biochemical metabolism. $\begin{array}{llll}\text { Agri. Sci., } & \text { v. 4, } & \text { p. 25-29, } 2013 .\end{array}$ http://dx.doi.org/10.4236/as. 2013.46A004

Yamaoka, L. H.; Skinner, D. M. Free amino acid pools in muscle and hemolymph during the molt cycle of the land crab, Gecarcinus lateralis. Comp. Biochem. Physiol., v. 55, p. 129-134, 1976. http://dx.doi.org/10.1016/03009629(76)90080-3

Zlatkis, A.; Zak, B.; Boyle, A. J. A new method for the direct determination of serum cholesterol. J. Lab. Clin. Med., v. 41, p. 486492, 1953. 